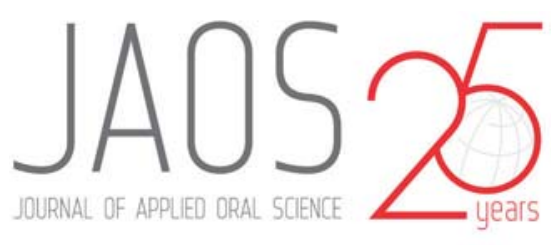

Luciane Geanini Pena dos SANTOS ${ }^{1}$ Wilson Tadeu FELIPPE ${ }^{1}$

Beatriz Dulcineia Mendes de SOUZA ${ }^{1}$ Andrea Cristina KONRATH ${ }^{2}$ Mabel Mariela Rodríguez CORDEIRO3 Mara Cristina Santos FELIPPE ${ }^{1}$

\section{Crown discoloration promoted by materials used in regenerative endodontic procedures and effect of dental bleaching: spectrophotometric analysis}

\section{Abstract}

Regenerative endodontic procedure (REP) has been proposed as a new approach to treat immature permanent teeth. However, materials used in REP for root canal disinfection or cervical sealing may induce tooth discoloration. Objectives: To assess tooth crown's color after intracanal treatment with triple antibiotic paste (TAP) or calcium hydroxide $(\mathrm{CH})$; cervical sealing with glass ionomer cement (GIC) or mineral trioxide aggregate (MTA); and bleaching with carbamide peroxide. Material and Methods: After pulp removal and color spectrophotometer measurement, 50 bovine incisors were divided into 4 experimental groups and one control (untreated). Experiments were performed in phases (Ph). Ph1: TAP (ciprofloxacin, metronidazole, minocycline), TAPM (ciprofloxacin, metronidazole, amoxicillin), DAP (ciprofloxacin, metronidazole), or $\mathrm{CH}$ treatment groups. After 1 and 3 days (d); 1, 2, 3 weeks (w); and 1, 2, 3 and 4 months (m), color was measured and medications were removed. Ph2: GIC or MTA cervical sealing, each using half of the specimens from each group. Color was assessed after $1 \mathrm{~d}$, 3d; 1w, 2w, 3w; 1m and 2m. Ph3: Two bleaching sessions, each followed by color measurement. Data were analyzed with ANOVA and post-hoc HolmSidak method. Results: Ph1: Specimens of TAP group presented higher color alteration $(\triangle E)$ mean than those of TAPM group. No significant difference was found among TAP or TAPM and $\mathrm{CH}$, DAP or Control groups. Ph2: cervical sealing materials showed no influence on color alteration. Ph3: Different $\Delta E$ means (from different groups), prior to bleaching, became equivalent after one bleaching session. Conclusions: TAP induces higher color alteration than TAPM; color alteration increases over time; cervical sealing material has no influence on color alteration; and, dental bleaching was able to recover, at least partially, the tooth crown's color.

Keywords: Regenerative endodontics. Spectrophotometry. Tooth discoloration. Triple antibiotic paste. Dental bleaching
${ }^{1}$ Universidade Federal de Santa Catarina, Departamento de Odontologia, Florianópolis, Santa Catarina, Brasil.

2Universidade Federal de Santa Catarina, Departamento de Informática e Estatística, Florianópolis, Santa Catarina, Brasil.

${ }^{3}$ Universidade Federal de Santa Catarina, Departamento de Ciências Morfológicas, Florianópolis,

Santa Catarina, Brasil. 


\section{Introduction}

Regenerative endodontic procedures (REP) have been proposed as an alternative to conventional endodontic treatment for immature permanent teeth, since it allows continuing root development in length and thickness $3,7,21,28$.

In Clinical Considerations for a Regenerative Procedure, American Association of Endodontists ${ }^{2}$ (AAE) advises root canal disinfection, blood clot formation and capping, cervical sealing, and crown restoration. For root canal disinfection, $A A^{2}$ recommends calcium hydroxide $(\mathrm{CH})$ or triple antibiotic paste (TAP), consisting of ciprofloxacin, metronidazole and minocycline ${ }^{12}$. Although TAP provides good antibacterial effect, case reports have shown tooth staining induced by minocycline ${ }^{9,16,23}$. Thus, alternative medications have been proposed, as double antibiotic paste (DAP), composed by ciprofloxacin and metronidazole ${ }^{24}$, or TAP Modified pastes (TAPM) in which minocycline is replaced by other antibiotics, as amoxicillin $^{14,24}$ or cefaclor ${ }^{24,27}$.

Subsequently to disinfection, $\mathrm{AAE}^{2}$ advises a 3-4 $\mathrm{mm}$ layer of MTA, bioceramic, or glass ionomer cement (GIC) over the capped clot as cervical sealing. Since even white MTA could induce tooth discoloration ${ }^{11,13}$, alternatives to this material, such as bioceramics and GIC, have been strongly indicated in teeth where there is an esthetic concern².

Although REP provides satisfactory biological results, products used in this approach could impair dental esthetic, which may not be reverted by tooth bleaching ${ }^{16,20}$. We did not find literature assessing tooth discoloration after each phase of REP, using different intracanal pastes and cervical sealing materials, followed by measuring color after bleaching. Therefore, investigation of alternatives to reduce tooth esthetic prejudice is justified. The aims of this study were to assess the effect of intracanal medications and sealing materials used in REP on tooth crown's color, as well as on tooth bleaching response. The null hypotheses are: (1) materials used as intracanal dressing or cervical sealing, in REP, are not able to induce tooth crown discoloration; and, (2) in case of tooth discoloration promoted by those materials, dental bleaching is not able to recover tooth color.

\section{Material and methods}

\section{Tooth selection and specimen preparation}

Fifty bovine incisors with similar dentinal wall thickness were collected and disinfected by immersion in $1.5 \%$ sodium hypochlorite for $3 \mathrm{~min}$. To simulate an immature tooth condition ${ }^{6}$ and standardize specimen length $(15 \mathrm{~mm})$, each tooth was sectioned $5 \mathrm{~mm}$ coronally and $10 \mathrm{~mm}$ radicularly from the cementumenamel junction (CEJ) using a water-cooled diamond disc. After endodontic access, pulp tissue was removed and the root canal was enlarged with a 4103 diamond bur (KG Sorensen, Barueri, SP, Brazil) under irrigation with $3 \mathrm{~mL}$ of $1.5 \% \mathrm{NaOCl}$, to standardize the internal diameter in $1.6 \mathrm{~mm}$ and thickness of dentinal walls in $1.91 \pm 0.37 \mathrm{~mm}$. The last radicular $5 \mathrm{~mm}$ were sealed with wax, and the root cervical third was irrigated with $3 \mathrm{~mL}$ of $1.5 \% \mathrm{NaOCl}$ followed by $3 \mathrm{~mL}$ of $17 \%$ ethylenediaminetetraacetic acid (EDTA, Sigma-Aldrich, St. Louis, United States) to remove smear layer. Root canal was dried with absorbent paper points, a cotton pellet was placed inside the root canal and the crown was sealed with Citodur ${ }^{\circledR}$ (DoriDent, Wien, Wien, Austria). During these procedures, teeth were wrapped up in gauzes embedded in distilled water to avoid dehydration; furthermore, after all preparations, they were stored submerged into $10 \mathrm{~mL}$ of distilled water.

\section{Spectrophotometry}

To standardize area and light conditions for color assessment, for each tooth, a custom silicone matrix was fabricated with impression material (Perfil ${ }^{\circledR}$, Vigodent S/A, Rio de J aneiro, RJ, Brazil), covering the entire buccal tooth surface. A perforation compatible with the size of the spectrophotometer tip $( \pm 6 \mathrm{~mm}$ diameter) was made with a cutting-edge cylinder at the crown area ${ }^{5}$ (Figure 1a-c). Specimens' colors were assessed using a digital spectrophotometer (Vita Easyshade $^{\circledR}$, VITA Zahnfabrik H. Rauter GmbH \& Co. KG, Bad Säckingen, Baden-Württemberg, Germany), and following the Commission Internationale de l'Éclairage (CIE) Lab System, to obtain L* (lightness), a* and b* (hue) values.

The first color assessment was performed one day after specimens' preparation and, before the assessment. For this, after removing specimens from distilled water, the excessive moisture of the external dental surface was removed with gauzes. After that, the experiment was performed in three phases: 

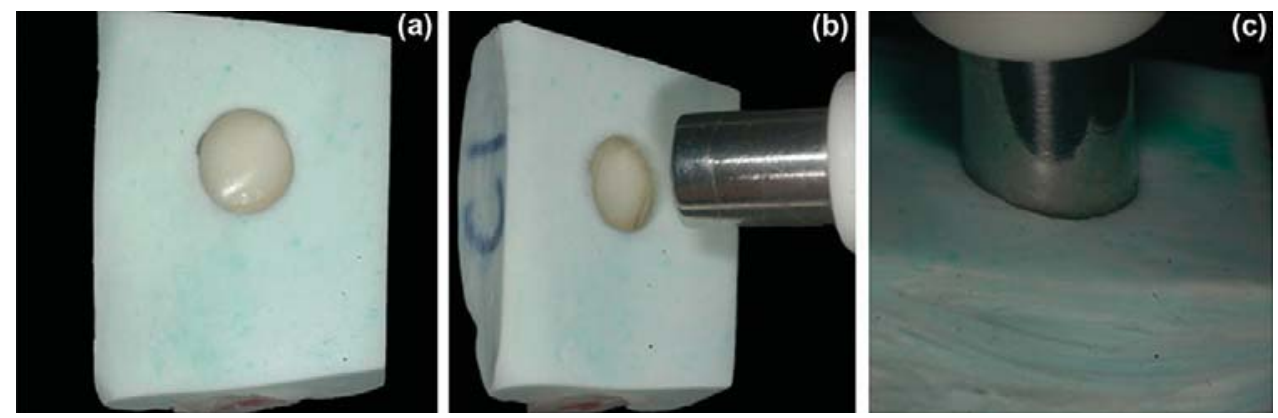

Figure 1- Tooth color assessment devices. (a) Custom silicone matrix covering the entire buccal tooth's surface, (b,c) with a perforation to fit the spectrophotometer tip.

\section{Phase 1: Intracanal medication}

Teeth were randomly divided into 1 control (root canal untreated) and 4 experimental groups $(n=10)$, according to intracanal medication: TAP; TAPM (ciprofloxacin, metronidazole, and amoxicillin); DAP; and $\mathrm{CH}$ (Calen ${ }^{\circledR}$, SS White, Rio de Janeiro, RJ, Brazil). Antibiotic pastes were prepared by the same pharmacy (Magistrale Farmácia de Manipulação, Florianópolis, SC, Brazil), at $0.1 \mathrm{mg} / \mathrm{mL}$ concentration and equal proportions of each antibiotic. All pastes were applied into the canals using syringe/needle (22 G1) (BD, Vernon Hills, IL, USA).

Coronal sealing was performed as previously described and teeth were stored once again in distilled water. After 1 and 3 days (d); 1, 2, and 3 weeks (w); and $1,2,3$, and 4 months $(\mathrm{m})$, specimens had the excessive moisture removed with gauzes and color shades were measured again.

Thereafter, intracanal medications were removed by saline solution irrigation and canals were dried with absorbent paper points for the next phase.

\section{Phase 2: Cervical sealing material}

Specimens from each experimental group were randomly subdivided into 2 subgroups $(n=5)$, according to the cervical sealing material: GIC (Vidrion $\mathrm{R}^{\circledR}$, SS White) or White MTA (Angelus, Londrina, PR, Brazil). Following coronal sealing, the specimens returned to the distilled water. After $1 d$ and $3 d ; 1 w, 2 w$, and $3 w$; and $1 \mathrm{~m}$ and $2 \mathrm{~m}$, color shades were registered again.

\section{Phase 3: Bleaching}

Coronal sealing was removed to perform dental bleaching with 37\% carbamide peroxide gel (BM4 Brasil Materiais e Instrumentais, Palhoça, SC, Brazil). Teeth were inserted in a polyurethane sponge soaked with distilled water up to the CEJ. Bleaching gel was applied inside and outside dental crowns for $45 \mathrm{~min}$, according to manufacturer's recommendations. Gel was then removed by suction, specimens were washed in distilled water, crowns sealed and teeth wetly stored. Color shades were assessed after 24 hours. Two bleaching sessions were performed at 1-week interval.

\section{Obtainment of color alteration}

For each specimen, the 3 parameters $(\Delta \mathrm{L}, \Delta \mathrm{a}$, $\Delta \mathrm{b})$ to measure color alteration $(\Delta \mathrm{E})$ were calculated subtracting the initial values from the final ones ( $\Delta \mathrm{L}=\mathrm{L} 2-\mathrm{L} 1, \Delta \mathrm{a}=\mathrm{a} 2-\mathrm{a} 1$, and $\Delta \mathrm{b}=\mathrm{b} 2-\mathrm{b} 1)$, at each time period. $\Delta \mathrm{E}$ means for each group and experimental period were calculated using the following equation:

$$
\Delta \mathrm{E}=\sqrt{(\Delta \mathrm{L})^{2}+(\Delta \mathrm{a})^{2}+(\Delta \mathrm{b})^{2}}
$$

It is important to highlight that $\Delta \mathrm{E}$ human perceptibility threshold was set at 3.7 units to determine which differences were clinically visible ${ }^{1,29}$. Therefore, any tooth color alteration higher than $\Delta \mathrm{E}$ : 3.7 would be perceived by the human eye.

\section{Statistical analysis}

Data were analyzed by Repeated Measures Analysis of Variance (ANOVA) and post-hoc Holm-Sidak method, at a significance level of $5 \%$.

\section{Results}

Supplemental Table 1 provides shades according to VITA Classical A1-D4 ${ }^{\circledR}$ Shade Guide from teeth throughout experiment.

\section{Phase 1: Intracanal medication}

As there was no significant difference in the interaction between treatment and periods $(P=0.121)$, the results from these variables were presented separately (Table 1, Figure 2). Disregarding the period, TAP group presented the highest $\triangle \mathrm{E}$ mean and there was a significant difference between TAP and TAPM 
groups. The latter showed $\Delta \mathrm{E}$ mean below human perception threshold value. However, no significant difference was found among these pastes and $\mathrm{CH}$, DAP, or Control.

Considering only experimental periods, the $\Delta \mathrm{E}$ means were equivalent and the lowest until the second week. On the other hand, the highest means were found at the last $3 \mathrm{~m}$ (Table 1 ).

Table 1- Mean values of $\Delta \mathrm{E}$ and confidence intervals according to treatment and period of evaluation regarding Phase 1 (Intracanal medication)

\begin{tabular}{|c|c|}
\hline Treatments & $\Delta E$ Mean \\
\hline TAP M & $3.5 \pm 0.5^{\mathrm{a}}$ \\
\hline CONTROL & $5.25 \pm 1.7^{\mathrm{ab}}$ \\
\hline DAB & $5.68 \pm 2.2^{\mathrm{ab}}$ \\
\hline $\mathrm{CH}$ & $6.16 \pm 1.9^{a b}$ \\
\hline TAP & $8.06 \pm 1.5^{b}$ \\
\hline Periods & $\Delta \mathrm{E}$ Mean \\
\hline $1 d$ & $4.21 \pm 2.9^{a}$ \\
\hline $3 d$ & $4.38 \pm 2.6^{a}$ \\
\hline $1 w$ & $4.42 \pm 2.8^{a}$ \\
\hline $2 w$ & $4.52 \pm 3.3^{\mathrm{ac}}$ \\
\hline $1 \mathrm{~m}$ & $5.83 \pm 5.1^{\text {ade }}$ \\
\hline $3 w$ & $6.15 \pm 3.0^{\mathrm{bd}}$ \\
\hline $4 m$ & $7.03 \pm 5.2^{\mathrm{bce}}$ \\
\hline $2 m$ & $7.34 \pm 5.9^{\text {be }}$ \\
\hline $3 m$ & $7.69 \pm 5.4^{b}$ \\
\hline
\end{tabular}

$\triangle \mathrm{E}$ : color change. $\mathrm{CH}$ : calcium hydroxide, DAP: double antibiotic paste, TAP: triple antibiotic paste, TAPM: TAP Modified. d: day, m: month, w: week. Treatment $(P=0.019)$. Period $(P<0.001)$. Equal letters indicate statistic equivalence.

\section{Phase 2: Cervical sealing material}

There was significant difference in the interaction between treatment and periods $(P<0.001)$. Thus, results from these variables are presented together (Table 2). At baseline, $\Delta \mathrm{E}$ means for different groups were different due to the effect of intracanal medication in Phase 1 . Only at $2 \mathrm{w}, \Delta \mathrm{E}$ means of TAP/ GIC and TAP/MTA groups were statistically different $(P=0.005)$. Considering absolute values, from $3 d$ to the end of this Phase, TAP/MTA group presented the highest $\triangle \mathrm{E}$ means, while, at the end, TAPM/GIC presented the lowest one. In the groups in which the pastes were associated with $\mathrm{GIC}$, there was a tendency to lower $\triangle E$ means than in those groups in which MTA was used. At some time points, TAPM/GIC and DAP/ GIC groups presented $\triangle \mathrm{E}$ means below the human perception threshold (Table 2, Figure 3).

\section{Phase 3: Bleaching}

Significant difference was found in the interaction between treatment and bleaching $(P<0.001)$, as presented in Table 2. At baseline, $\Delta \mathrm{E}$ means of this Phase 3 were different due to the effect of the materials used in Phase 2. There was a tendency to $\Delta \mathrm{E}$ mean decrease after bleaching. After the first session, TAP/MTA $\triangle E$ mean decreased and showed equivalence with other groups' outcomes. No difference was found comparing $\Delta \mathrm{E}$ means with the first and the second bleaching sessions within the same group.

It is worth pointing out that in $\mathrm{CH}$ /MTA group the $\Delta \mathrm{E}$ mean after the second bleaching increased and became higher than at baseline (Figure 4, Table 2).

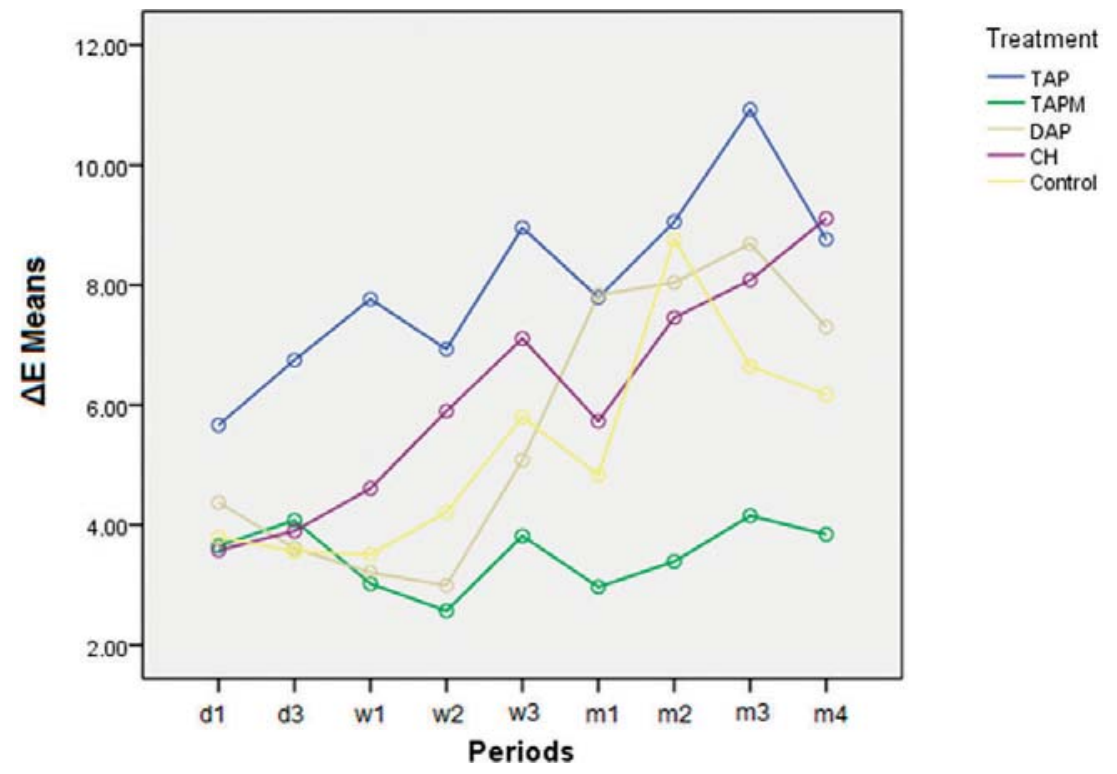

Figure 2- Graphic illustrating $\Delta \mathrm{E}$ means from each group and period throughout Phase 1 
Table 2- Mean values of $\Delta \mathrm{E}$ and standard deviation in Phase 2 (Treatment ${ }^{\star}$ Periods) and in Phase 3 (Treatment ${ }^{\star}$ Bleaching)

\begin{tabular}{|c|c|c|c|c|c|c|c|c|c|}
\hline & \multicolumn{2}{|c|}{ TAP } & \multicolumn{2}{|c|}{ TAPM } & \multicolumn{2}{|c|}{ DAP } & \multicolumn{2}{|c|}{$\mathrm{CH}$} & \multirow[t]{2}{*}{ Control } \\
\hline & GIC & MTA & GIC & MTA & GIC & MTA & GIC & MTA & \\
\hline Period & \multicolumn{9}{|c|}{ Phase 2. Cervical Sealing } \\
\hline Baseline & $7.77 \pm 0.9^{\mathrm{abA}}$ & $9.74 \pm 5.8^{\mathrm{abA}}$ & $3.46 \pm 1.3^{\mathrm{aA}}$ & $4.23 \pm 2.2^{\mathrm{acA}}$ & $2.66 \pm 1.4^{\mathrm{abA}}$ & $11.94 \pm 11.0^{\mathrm{abA}}$ & $10.48 \pm 5.3^{\mathrm{acf} A}$ & $7.73 \pm 4.6^{\mathrm{acdA}}$ & $6.17 \pm 2.7^{\mathrm{acA}}$ \\
\hline $1 d$ & $7.29 \pm 1.3^{\mathrm{abAF}}$ & $10 \pm 5.5^{\mathrm{aACF}}$ & $3.73 \pm 2.6^{\mathrm{aA}}$ & $3.85 \pm 0.9^{\mathrm{aA}}$ & $10.18 \pm 1.5^{\mathrm{aAE}}$ & $12.12 \pm 3.8^{\mathrm{aDEF}}$ & $13.98 \pm 1.8^{\mathrm{aDEF}}$ & $15.71 \pm 3.3^{\mathrm{aBCE}}$ & $13.61 \pm 3.4^{\mathrm{bBCE}}$ \\
\hline $3 d$ & $6.65 \pm 4.4^{\mathrm{aAE}}$ & $11.83 \pm 3.2^{\mathrm{abA}}$ & $9.01 \pm 2.0^{\mathrm{cAC}}$ & $8.66 \pm 1.6^{\mathrm{cAD}}$ & $3.66 \pm 1.5^{\mathrm{bBCDE}}$ & $7.9 \pm 2.5^{\mathrm{bCAE}}$ & $7.96 \pm 2.4^{\mathrm{bcAE}}$ & $8.88 \pm 3.2^{\mathrm{bcAE}}$ & $5.72 \pm 1.3^{\mathrm{aBCDE}}$ \\
\hline $1 w$ & $10.41 \pm 6.6^{\mathrm{bA}}$ & $14.47 \pm 4.1^{\mathrm{abA}}$ & $12.31 \pm 0.3^{\mathrm{bA}}$ & $13.27 \pm 0.6^{\mathrm{bA}}$ & $10.07 \pm 1.3^{\mathrm{acA}}$ & $10.68 \pm 5.5^{\text {acdA }}$ & $11.86 \pm 1.3^{\text {adA }}$ & $11.96 \pm 2.6^{\mathrm{acA}}$ & $9.4 \pm 2.6^{\mathrm{cA}}$ \\
\hline $2 w$ & $6.04 \pm 2.7^{\mathrm{aA}}$ & $12.31 \pm 5.0^{\mathrm{abBC}}$ & $4.26 \pm 0.3^{\mathrm{aA}}$ & $5.98 \pm 0.8^{\mathrm{aA}}$ & $2.56 \pm 0.7^{\mathrm{bA}}$ & $6.23 \pm 1.7^{\mathrm{bA}}$ & $7.45 \pm 2.4^{\text {beAc }}$ & $6.87 \pm 2.6^{\mathrm{bdA}}$ & $4.34 \pm 1.5^{\mathrm{aA}}$ \\
\hline $3 w$ & $7.42 \pm 0.4^{\mathrm{abAB}}$ & $12.45 \pm 5.2^{\mathrm{abA}}$ & $2.55 \pm 1.1^{\mathrm{aB}}$ & $4.17 \pm 1.0^{\mathrm{acB}}$ & $2.53 \pm 1.3^{\text {бв }}$ & $5.1 \pm 2.9^{\mathrm{bdAB}}$ & $6.59 \pm 3.0^{\mathrm{bdfAB}}$ & $8.91 \pm 8.5^{\mathrm{bcAB}}$ & $4.34 \pm 1.6^{\mathrm{acB}}$ \\
\hline $1 \mathrm{~m}$ & $8.21 \pm 2.0^{\mathrm{abAC}}$ & $15.8 \pm 9.4^{\mathrm{bA}}$ & $2.70 \pm 0.4^{\mathrm{aBC}}$ & $4.86 \pm 0.7^{\mathrm{acBC}}$ & $2.49 \pm 0.5^{\mathrm{bBC}}$ & $5.18 \pm 2.3^{\mathrm{bdBC}}$ & $10 \pm 3.6^{\text {acefAC }}$ & $6.26 \pm 2.9^{\mathrm{bcBC}}$ & $4.57 \pm 1.7^{\mathrm{aBC}}$ \\
\hline $2 m$ & $9.13 \pm 1.8^{\mathrm{abAC}}$ & $13.72 \pm 5.5^{\mathrm{abA}}$ & $3.63 \pm 1.4^{\mathrm{aBC}}$ & $6.04 \pm 1.8^{\mathrm{acBC}}$ & $4.75 \pm 2.2^{\mathrm{bcBC}}$ & $7.18 \pm 2.0^{\mathrm{bdBC}}$ & $9.36 \pm 3.3^{\text {acefAC }}$ & $8.23 \pm 3.1^{\mathrm{bcAC}}$ & $6.33 \pm 2.1^{\mathrm{acBC}}$ \\
\hline Bleaching & \multicolumn{9}{|c|}{ Phase 3. Bleaching } \\
\hline Baseline & $9.13 \pm 1.8^{\mathrm{aAB}}$ & $13.72 \pm 5.5^{\mathrm{aA}}$ & $3.63 \pm 1.4^{\mathrm{aB}}$ & $6.04 \pm 1.8^{\mathrm{aB}}$ & $4.75 \pm 2.2^{\mathrm{aB}}$ & $7.18 \pm 2.0^{\mathrm{aB}}$ & $9.36 \pm 3.3^{\mathrm{aAB}}$ & $8.23 \pm 3.1^{\mathrm{acAB}}$ & $6.33 \pm 2.1^{\mathrm{aB}}$ \\
\hline B1 & $5.05 \pm 2.4^{\mathrm{bA}}$ & $6.87 \pm 5.2^{\mathrm{bA}}$ & $4.76 \pm 2.5^{\mathrm{aA}}$ & $4.19 \pm 0.7^{\mathrm{aA}}$ & $4.88 \pm 2.2^{\mathrm{aA}}$ & $7.1 \pm 3.8^{\mathrm{aA}}$ & $5.54 \pm 2.1^{\mathrm{bA}}$ & $6.74 \pm 1.5^{\mathrm{aA}}$ & $5.93 \pm 1.3^{\mathrm{aA}}$ \\
\hline B2 & $4.93 \pm 2.1^{\mathrm{bA}}$ & $6.48 \pm 3.4^{\mathrm{bA}}$ & $5.59 \pm 2.2^{\mathrm{aA}}$ & $4.65 \pm 08^{\mathrm{aA}}$ & $6.88 \pm 1.5^{\mathrm{aA}}$ & $6.33 \pm 5.5^{\mathrm{aA}}$ & $4.19 \pm 1.5^{\mathrm{bA}}$ & $9.87 \pm 4.9^{\mathrm{bcA}}$ & $6.67 \pm 2.3^{\mathrm{aA}}$ \\
\hline
\end{tabular}

$\triangle \mathrm{E}$ : color change. B1: bleaching 1, B2: bleaching 2. $\mathrm{CH}$ : calcium hydroxide, DAP: double antibiotic paste, TAP: triple antibiotic paste, TAPM: TAP modified. GIC: glass ionomer cement, MTA: mineral trioxide aggregate. d: day, m: month, w: week. For comparisons, lowercase letters were used within the columns and uppercase letters within the rows. Equal letters indicate statistic equivalence. Phase 2: Treatment ${ }^{*}$ Period $(P<0.001)$. Phase 3: Treatment ${ }^{*}$ Bleaching $(P<0.001)$.
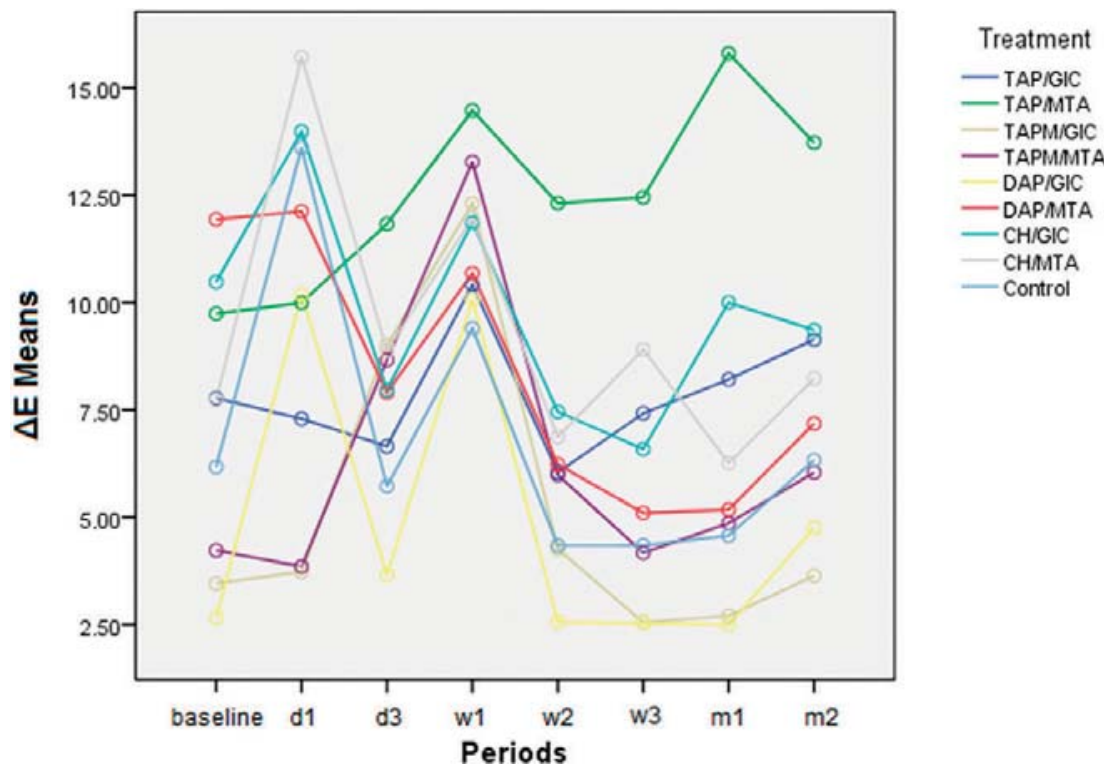

Figure 3- Graphic illustrating $\Delta \mathrm{E}$ means from each group and period throughout Phase 2

Despite the numerical increase in $\Delta \mathrm{E}$ mean, color shades according to VITA Classical A1-D4 ${ }^{\circledR}$ Shade Guide did not change in most samples (Supplemental Table 1).

\section{Discussion}

Proposed as a therapy for immature permanent teeth, regenerative endodontic procedures have been related to tooth discoloration ${ }^{10,16,23}$, which could eventually lead to psychological implications ${ }^{26}$. So, it is important to search for treatments esthetically predictable.

Although TAP provides suitable antibacterial effect $^{12}$, the minocycline in its composition has been associated with dental staining 9,16,23. Thus, researchers have looked for alternatives to TAP composition 14,24,27. In this study, TAP, TAPM (amoxicillin replacing minocycline), DAP (TAP without minocycline) and $\mathrm{CH}$ pastes were used. In Phase 1, TAP showed highest color alteration, while TAPM showed the lowest one. These results suggest that replacing minocycline with amoxicillin can lead to minor dental color change, improving esthetic results of REP. When minocycline 

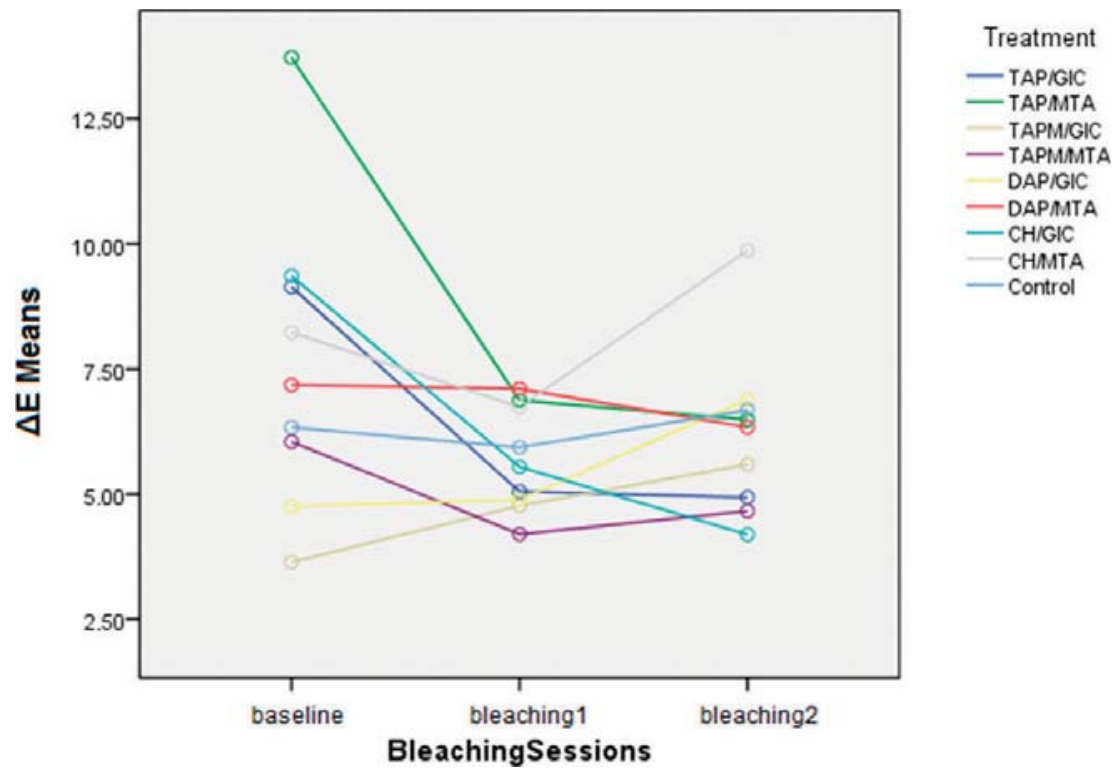

Figure 4- Graphic illustrating $\Delta \mathrm{E}$ means from each group and period throughout Phase 3

was abolished (DAP), color change was lower than in TAP and higher than in TAPM groups. Although no statistically significant difference was found between DAP and TAPM, regarding tooth color stability, results suggest that antibiotic replacing is better than its suppression. However, this result was different from that found by Akcay, et al. ${ }^{1}$ (2014), in which "TAP with amoxicillin" showed higher $\Delta \mathrm{E}$ means than DAP group. Nevertheless, while in this study the pastes were prepared according to $\mathrm{AAE}^{2}$ recommendations $(0.1 \mathrm{mg} / \mathrm{mL})$, in the study of those authors the final concentration of pastes is unknown.

All groups showed variations in $\Delta \mathrm{E}$ means through all experimental phases, and even Control group showed some color change. This result may be explained by hydration/dehydration of dental structure, which can lead to color alterations. Dehydration would result in replacement of water by air around the enamel prisms. At a dehydrated enamel-air interface, the refractive and scattering indices are different from those of enamel-water interface. Dehydrated enamel would show lower translucency causing more reflection, thus masking the underlying dentine shade, leading to a lighter appearance ${ }^{8}$. In this study, to reduce the effect of water loss during procedures, the time for rehydration was established in $24 \mathrm{~h}$ prior to color measurements. Even being careful to remove just the excessive moisture from the external dental surface and short manipulation time ( \pm 1 minute) to take color shade, some color alteration was expected ${ }^{8,25}$, since the major color change in dehydrated teeth occur in the first 10 minutes $^{8}$.
When cervical sealing was performed, dental structure was under the effect of intracanal medication used in Phase 1. Thus, in Phase 2 the groups started from different values. It was observed that from $3 d$ until the end of this Phase, the highest color alterations were registered for TAP/MTA. Although significant difference was found between TAP/MTA and TAP/GIC only at $2 \mathrm{w}$, this result is especially interesting since the association TAP/MTA has been largely used in clinical practice. It is worth pointing out that in the groups in which pastes were associated with GIC, generally, $\Delta \mathrm{E}$ means were lower than those found when they were associated with MTA, although no significant difference was found. This was expected since studies have reported that even white MTA can lead to dental staining ${ }^{11,13}$. The results of this study confirm the $A A E^{2}$ advice of applying GIC instead of MTA as cervical sealing material in areas where there is an esthetic concern.

In this study, a $37 \%$ carbamide peroxide gel was applied inside and outside crown structure according to manufacturer's recommendations. This technique is largely used to bleach non-vital teeth. Although REP aims to form new vital tissue within the root canal, the coronal pulp space remains empty. This particular situation allows treating "vital teeth" by a technique indicated to non-vital teeth, because cervical sealing materials protect the vital tissue from the bleaching agent.

Interestingly, it was observed that the $\Delta \mathrm{E}$ means of TAP/MTA group became similar to the other groups after the first bleaching session. Furthermore, except 
Supplemental Table 1- Color shades of the samples according to VITA Classical A1-D4 ${ }^{\circledR}$ Shade Guide throughout the experiment.

\begin{tabular}{|c|c|c|c|c|c|c|c|c|c|c|c|c|}
\hline \multirow[t]{2}{*}{ GROUP } & \multirow[t]{2}{*}{ SAMPLE } & \multirow[t]{2}{*}{ BASELINE } & \multicolumn{4}{|c|}{ INTRACANAL MEDICATION } & \multicolumn{3}{|c|}{ CERVICAL SEALING } & \multicolumn{2}{|c|}{ BLEACHING } & \\
\hline & & & $1 w$ & $1 \mathrm{~m}$ & $2 \mathrm{~m}$ & $4 m$ & $1 w$ & $1 \mathrm{~m}$ & $2 m$ & SESSION1 & SESSION2 & \\
\hline \multirow[t]{10}{*}{ TAP } & 1 & B1 & B2 & B2 & B2 & B2 & B2 & B2 & B2 & B2 & $\mathrm{A} 1$ & GIC \\
\hline & 2 & $\mathrm{~A} 1$ & B2 & B2 & B2 & B2 & B2 & B2 & B2 & B2 & $\mathrm{A} 1$ & \\
\hline & 3 & $\mathrm{~A} 2$ & B2 & B2 & B2 & B2 & B3 & B2 & B2 & B2 & $\mathrm{A} 1$ & \\
\hline & 4 & B2 & B2 & B2 & B2 & B2 & B3 & B2 & B2 & A1 & $\mathrm{A} 1$ & \\
\hline & 5 & $\mathrm{~A} 2$ & $\mathrm{~A} 2$ & $\mathrm{~A} 2$ & B2 & B2 & $\mathrm{A} 2$ & B2 & B3 & $\mathrm{A} 2$ & A2 & \\
\hline & 6 & $\mathrm{~A} 1$ & B2 & B2 & B2 & B2 & B3 & B3 & B3 & $\mathrm{A} 1$ & $\mathrm{~A} 1$ & MTA \\
\hline & 7 & B1 & B2 & B2 & B2 & B2 & B2 & B3 & B2 & B2 & B2 & \\
\hline & 8 & $\mathrm{~A} 2$ & $\mathrm{~A} 2$ & $\mathrm{~A} 2$ & $\mathrm{~A} 2$ & B2 & B3 & B3 & B3 & B2 & B2 & \\
\hline & 9 & $\mathrm{~A} 1$ & B2 & B2 & B2 & B2 & B2 & B2 & B2 & $\mathrm{A} 1$ & B2 & \\
\hline & 10 & $\mathrm{~A} 2$ & A2 & $\mathrm{A} 2$ & $\mathrm{~A} 2$ & B2 & B3 & B3 & B3 & B2 & B2 & \\
\hline \multirow[t]{10}{*}{ TAPM } & 11 & B2 & B2 & $\mathrm{A} 1$ & $\mathrm{~A} 1$ & B2 & B2 & B2 & B2 & $\mathrm{A} 1$ & $\mathrm{~A} 1$ & GIC \\
\hline & 12 & $\mathrm{~A} 1$ & $\mathrm{~A} 1$ & $\mathrm{~A} 1$ & $\mathrm{~A} 2$ & $\mathrm{~A} 1$ & B2 & B2 & B2 & $\mathrm{A} 1$ & $\mathrm{~A} 1$ & \\
\hline & 13 & B2 & B2 & B2 & B2 & B2 & B2 & B2 & B2 & B2 & $\mathrm{A} 1$ & \\
\hline & 14 & $\mathrm{~A} 2$ & $\mathrm{~A} 2$ & $\mathrm{~A} 2$ & B2 & B2 & $\mathrm{A} 2$ & $\mathrm{~A} 2$ & B2 & B2 & B2 & \\
\hline & 15 & $\mathrm{~A} 2$ & $\mathrm{~A} 2$ & $\mathrm{~A} 2$ & $\mathrm{~A} 2$ & $\mathrm{~A} 2$ & $\mathrm{~A} 2$ & $\mathrm{~A} 2$ & $\mathrm{~A} 2$ & B2 & $\mathrm{A} 1$ & \\
\hline & 16 & $\mathrm{~A} 1$ & $\mathrm{~A} 1$ & $\mathrm{~A} 1$ & $\mathrm{~A} 1$ & $\mathrm{~A} 1$ & B2 & B2 & B2 & B2 & B2 & MTA \\
\hline & 17 & A3 & A3 & A3 & A3 & A3 & B3 & B3 & B3 & B3 & B3 & \\
\hline & 18 & $\mathrm{~A} 2$ & A3 & $\mathrm{A} 2$ & A3 & A2 & A3 & B3 & B3 & B3 & B2 & \\
\hline & 19 & $\mathrm{~A} 2$ & A3 & A3 & A3 & $\mathrm{A} 2$ & B3 & B3 & B3 & B3 & B3 & \\
\hline & 20 & $\mathrm{~A} 1$ & $\mathrm{~A} 1$ & $\mathrm{~A} 1$ & B2 & B2 & B2 & B2 & B2 & $\mathrm{A} 1$ & $\mathrm{~A} 1$ & \\
\hline \multirow[t]{10}{*}{ DAB } & 21 & $\mathrm{~A} 2$ & $\mathrm{~A} 2$ & B2 & $\mathrm{A} 2$ & $\mathrm{~A} 2$ & B3 & B2 & B3 & $\mathrm{A} 2$ & B2 & GIC \\
\hline & 22 & $\mathrm{~A} 1$ & $\mathrm{~A} 1$ & $\mathrm{~A} 1$ & B2 & B2 & B2 & B2 & B2 & $\mathrm{A} 1$ & B1 & \\
\hline & 23 & $\mathrm{~A} 1$ & $\mathrm{~A} 1$ & $\mathrm{~A} 1$ & B2 & B2 & B2 & B2 & B2 & B1 & B1 & \\
\hline & 24 & B2 & B2 & $\mathrm{A} 2$ & $\mathrm{~A} 2$ & B2 & B3 & B2 & B2 & B2 & A1 & \\
\hline & 25 & B2 & B2 & B1 & B2 & B2 & B2 & B2 & B2 & $\mathrm{A} 1$ & $\mathrm{~A} 1$ & \\
\hline & 26 & A3 & $\mathrm{A} 2$ & A3 & B3 & B3 & B3 & B3 & B3 & B3 & B3 & MTA \\
\hline & 27 & $\mathrm{~A} 2$ & $\mathrm{~A} 2$ & $\mathrm{~A} 2$ & $\mathrm{~A} 2$ & $\mathrm{~A} 2$ & B2 & B2 & B3 & B2 & B2 & \\
\hline & 28 & A3.5 & A3.5 & A3.5 & A. 35 & A3.5 & A3.5 & A3.5 & B4 & B3 & B3 & \\
\hline & 29 & B2 & B2 & B2 & B2 & B2 & B2 & B2 & B2 & $\mathrm{A} 1$ & A1 & \\
\hline & 30 & $\mathrm{~A} 1$ & $\mathrm{~A} 2$ & B2 & $\mathrm{A} 2$ & B2 & B3 & B2 & B2 & B2 & B2 & \\
\hline \multirow[t]{10}{*}{$\mathrm{CH}$} & 31 & B1 & B2 & B2 & B2 & B2 & B2 & B2 & B2 & B2 & $\mathrm{A} 1$ & GIC \\
\hline & 32 & $\mathrm{~A} 1$ & B2 & B2 & B2 & B3 & B2 & B2 & B2 & $\mathrm{A} 1$ & $\mathrm{~A} 1$ & \\
\hline & 33 & $\mathrm{~A} 1$ & B2 & B2 & B2 & B2 & B2 & B2 & B2 & B2 & B2 & \\
\hline & 34 & B2 & B2 & B2 & B2 & B2 & B3 & B2 & B2 & B2 & $\mathrm{A} 1$ & \\
\hline & 35 & $\mathrm{~A} 2$ & $\mathrm{~A} 2$ & B2 & B2 & B2 & B2 & B2 & B2 & B2 & B2 & \\
\hline & 36 & B2 & B2 & B2 & B2 & B2 & B2 & B2 & B2 & B2 & B2 & MTA \\
\hline & 37 & $\mathrm{~A} 1$ & B2 & B2 & B2 & B2 & B2 & B2 & B2 & B2 & B2 & \\
\hline & 38 & $\mathrm{~A} 2$ & B3 & B3 & B3 & B3 & B3 & B3 & B3 & B2 & B2 & \\
\hline & 39 & A2 & A3 & A3 & B3 & B2 & B3 & B3 & B3 & B3 & B3 & \\
\hline & 40 & $\mathrm{~A} 2$ & $\mathrm{~A} 2$ & B2 & B2 & B2 & B3 & B2 & B2 & B2 & B2 & \\
\hline \multirow[t]{10}{*}{ Control } & 41 & B2 & B2 & B2 & B2 & $\mathrm{A} 1$ & B2 & B2 & B2 & B2 & B2 & UT \\
\hline & 42 & $\mathrm{~A} 1$ & $\mathrm{~A} 1$ & $\mathrm{~A} 1$ & B2 & $\mathrm{A} 2$ & B2 & $\mathrm{A} 1$ & $\mathrm{~A} 1$ & $\mathrm{~A} 1$ & $\mathrm{~A} 1$ & \\
\hline & 43 & $\mathrm{~A} 2$ & $\mathrm{~A} 2$ & $\mathrm{~A} 2$ & $\mathrm{~A} 2$ & B2 & B2 & B2 & B2 & B2 & B2 & \\
\hline & 44 & $\mathrm{~A} 1$ & $\mathrm{~A} 1$ & $\mathrm{~A} 1$ & $\mathrm{C} 2$ & $\mathrm{~A} 1$ & B2 & $\mathrm{A} 1$ & B2 & $\mathrm{A} 1$ & $\mathrm{~A} 1$ & \\
\hline & 45 & $\mathrm{~A} 2$ & $\mathrm{~A} 2$ & $\mathrm{~A} 1$ & $\mathrm{~A} 2$ & B2 & B2 & B2 & B2 & B2 & B2 & \\
\hline & 46 & B2 & B2 & B2 & A3 & B2 & B2 & B2 & B2 & B2 & B2 & \\
\hline & 47 & $\mathrm{~A} 1$ & $\mathrm{~A} 1$ & $\mathrm{~A} 1$ & B2 & $\mathrm{A} 1$ & B2 & $\mathrm{A} 1$ & $\mathrm{~A} 1$ & $\mathrm{~A} 1$ & $\mathrm{~A} 1$ & \\
\hline & 48 & $\mathrm{~A} 2$ & $\mathrm{~A} 2$ & $\mathrm{~A} 2$ & B2 & B2 & B2 & B2 & B2 & B2 & B2 & \\
\hline & 49 & $\mathrm{~A} 1$ & $\mathrm{~A} 1$ & $\mathrm{~A} 1$ & $\mathrm{~A} 2$ & $\mathrm{~A} 2$ & B2 & $\mathrm{A} 1$ & B2 & $\mathrm{A} 1$ & B2 & \\
\hline & 50 & B2 & $\mathrm{A} 2$ & $\mathrm{~A} 2$ & B2 & $\mathrm{A} 1$ & B2 & B2 & B2 & B2 & B2 & \\
\hline
\end{tabular}

$\mathrm{CH}$ : calcium hydroxide, DAP: double antibiotic paste, TAP: triple antibiotic paste, TAPM: TAP modified. GIC: glass ionomer cement, MTA: mineral trioxide aggregate, UT: untreated. d: day, m: month, w: week. 
for $\mathrm{CH} / \mathrm{MTA}$ group, no difference was found after one or two bleaching sessions. This suggests that, under these experimental conditions, only one session might be enough to improve tooth color. This result is clinically important considering the number of dental interventions and appointments, which reflects in treatment costs.

Despite the fact that there was a reduction in $\Delta \mathrm{E}$ mean after the first bleaching session in $\mathrm{CH} / \mathrm{MTA}$ group, it turned to increase in such a way that, after the second session, the mean ended higher than the registered at the baseline of this Phase. This may be explained by two hypotheses. First, the presence of oxygen in all materials used $(\mathrm{CH}, \mathrm{MTA}$, and carbamide peroxide) may be related to the overoxidation of bismuth oxide ${ }^{15}$, which is the radiopacifier of MTA Bismuth oxide has been related to tooth staining when in contact with dentin matrix collagen ${ }^{19}$. Another explanation may be the interactions among the different materials used, which could produce formaldehyde as a byproduct of chemical reactions. Bismuth oxide and calcium oxide could stain dental structure when in contact with formaldehyde 4 . However, even with the increase in $\Delta \mathrm{E}$ mean, tooth shades, according to VITA Classical A1-D4 ${ }^{\circledR}$ Shade Guide, did not change between the first and the second bleaching. It is possible since small color difference may not determine the change of a shade for another, as there is an interval in referential values of $L^{*}, a^{*}$, and, $b^{*}$ between shades ${ }^{22}$.

A digital spectrophotometer was used to register tooth shades along the three experimental phases. From this device, it is possible to obtain values of " $L$ ", " $a$ " and " $b$ " of the dental structure and, then, calculate $\Delta \mathrm{E}$ between time points. Spectrophotometers became largely used in Dentistry due to their reliable method of reading tooth color shade. Here, Vita Easyshade ${ }^{\circledR}$ was used as it has high reliability and accuracy ${ }^{17}$. Additionally to the numerical information of lightness and hue, this device provides shades according to VITA Classical A1-D4 ${ }^{\circledR}$ Shade Guide, a standard and worldwide reference system in tooth shade determination. To further avoid external influences, silicone matrices were customized to ensure standardized area and light conditions along the experimental phases ${ }^{5}$. The selection of teeth with similar dentinal wall thickness is also important to improve standardized conditions ${ }^{18}$ and, consequently, to improve reliability of the comparisons along the time.

Here, it was investigated the effect on dental crown discoloration of products used as intracanal medication or cervical sealing in regenerative endodontics procedures, as well as the impact of dental bleaching after regenerative approach. Under limitations of an ex vivo study, the methodology was designed to simulate procedures performed in clinics, applying sequentially products on the same tooth to assess, throughout the experimental phases, the impact of each of them on tooth color shade.

\section{Conclusion}

From the results of this experimental ex vivo study, we conclude that the evaluated intracanal medications, which are applied in regenerative endodontic approaches, influence tooth discoloration over time, being TAP the material that induces higher color alteration. On the other hand, cervical sealing material has no influence on tooth discoloration. Furthermore, dental bleaching was able to recover, at least partially, tooth color shade, mainly at first application.

\section{References}

1- Akcay M, Arslan H, Yasa B, Kavrık F, Yasa E. Spectrophotometric analysis of crown discoloration induced by various antibiotic pastes used in revascularization. J Endod. 2014;40(6):845-8.

2- American Association of Endodontics. Regenerative endodontics [Internet]. Chicago: American Association of Endodontists; 2015 [cited 2017 J an 20]. Available from: http://www. aae.org/regenerativeendo/. 3- Banchs F, Trope M. Revascularization of immature permanent teeth with apical periodontitis: new treatment protocol? J Endod. 2004; 30(4): 196-200.

4- Berger T, Baratz AZ, Gutmann JL. In vitro investigations into the etiology of mineral trioxide tooth staining. J Conserv Dent. 2014; 17(6): 526-30

5- Bernardon JK, Sartori N, Ballarin A, Perdigão J, Lopes GC, Baratieri LN. Clinical performance of vital bleaching techniques. Oper Dent. 2010; 35(1): 3-10.

6- Bortoluzzi EA, Souza EM, Reis JM, Esberard RM, Tanomaru-Filho $M$. Fracture strength of bovine incisors after intra-radicular treatment with MTA in an experimental immature tooth model. Int Endod J. 2007; 40(9):684-91.

7- Bose R, Nummikoski P, Hargreaves K. A retrospective evaluation of radiographic outcomes in immature teeth with necrotic root canal systems treated with regenerative endodontic procedures. J Endod. 2009; 35(10): 1343-9

8- Burki Z, Watkins S, Wilson R, Fenlon M. A randomised controlled trial to investigate the effects of dehydration on tooth colour. J Dent. 2013;41(3):250-7.

9- Dabbagh B, Alvaro E, Vu DD, Rizkallah J, Schwartz S. Clinica complications in the revascularization of immature necrotic permanent teeth. Pediatr Dent. 2012;34(5):414-7. 
10- Ding RY, Cheung GS, Chen J, Yin XZ, Wang QQ, Zhang CF. Pulp revascularization of immature teeth with apical periodontitis: a clinical study. J Endod. 2009; 35(5): 745-9.

11- Felman D, Parashos P. Coronal tooth discoloration and white mineral trioxide aggregate. J Endod. 2013;39(4):484-7.

12- Hoshino E, Kurihara-Ando N, Sato I, Uematsu H, Sato M, Kota $K$, et al. In-vitro antibacterial susceptibility of bacteria taken from infected root dentine to a mixture of ciprofloxacin, metronidazole and minocycline. Int Endod J. 1996;29(2): 125-30.

13- I oannidis K, Mistakidis I, Beltes P, Karagiannis V. Spectrophotometric analysis of coronal discolouration induced by grey and white MTA. Int Endod J. 2013; 46(2): 137-44.

14- Kahler B, Mistry S, Moule A, Ringsmuth AK, Case P, Thomson $A$, et al. Revascularization outcomes: a prospective analysis of 16 consecutive cases. J Endod. 2014;40(3):333-8.

15- Kang SH, Shin YS, Lee HS, Kim SO, Shin Y, Jung IY, et al. Color changes of teeth after treatment with various mineral trioxide aggregate-based materials: an ex vivo study. J Endod. 2015;41(5): 73741.

16- Kim JH, Kim Y, Shin SJ, Park JW, Jung IY. Tooth discoloration of immature permanent incisor associated with triple antibiotic therapy: a case report. J Endod. 2010;36(6): 1086-91.

17- Kim-Pusateri S, Brewer JD, Davis EL, Wee AG. Reliability and accuracy of four dental shade-matching devices. J Prosthet Dent. 2009; 101(3): 193-9.

18- Lenherr P, Allgayer N, Weiger R, Filippi A, Attin T, Krastl G. Tooth discoloration induced by endodontic materials: a laboratory study. Int Endod J. 2012; 45(10): 942-9.

19- Marciano MA, Costa RM, Camilleri J, Mondelli RF, Guimarães BM, Duarte MA. Assessment of color stability of white mineral trioxide aggregate angelus and bismuth oxide in contact with tooth structure. J Endod. 2014;40(8): 1235-40.
20- Miller EK, Lee JY, Tawil PZ, Teixeira FB, Vann WF Jr. Emerging therapies for the management of traumatized immature permanent incisors. Pediatr Dent. 2012;34(1):66-9.

21- Nosrat A, Seifi A, Asgary S. Regenerative endodontic treatment (revascularization) for necrotic immature permanent molars: a review and report of two cases with a new biomaterial. J Endod. $2011 ; 37(4): 562-7$.

22- O'brien WJ, Groh CL, Boenke KM. A new, small-color-difference equation for dental shades. J Dent Res. 1990;69(11):1762-4.

23- Petrino JA, Boda KK, Shambarger S, Bowles WR, McClanahan SB. Challenges in regenerative endodontics: a case series. J Endod. 2010; 36(3): 536-41.

24- Ruparel NB, Teixeira FB, Ferraz CC, Diogenes A. Direct effect of intracanal medicaments on survival of stem cells of the apical papilla. J Endod. 2012; 38(10): 1372-5.

25- Russell MD, Gulfraz M, Moss BW. In vivo measurement of colour changes in natural teeth. J Oral Rehabil. 2000;27(9): 786-92.

26- Seehra J, Newton JT, Dibiase AT. Bullying in schoolchildren - its relationship to dental appearance and psychosocial implications: an update for GDPs. Br Dent J. 2011;210(9):411-5.

27- Thibodeau B, Trope M. Pulp revascularization of a necrotic infected immature permanent tooth: case report and review of the literature. Pediatr Dent. 2007;29(1):47-50.

28- Trope M. Treatment of immature teeth with non-vital pulps and apical periodontitis. Endod Top. 2006; 14:51-9.

29- Yuan JC, Brewer JD, Monaco EA Jr, Davis EL. Defining a natural tooth color space based on a 3-dimensional shade system. J Prosthet Dent. 2007; 98(2): 110-9. 